\title{
Physical-Chemical Characteristics of South Aceh Marble and Its Suitability for Tiles Application
}

\author{
L. Lindawati ${ }^{\text {ab }}$, I. Irwansyah ${ }^{\mathrm{a}}$, N. Fitriadi ${ }^{\mathrm{a}}$, M. Silviana ${ }^{\mathrm{c}}$ \\ ${ }^{a}$ Departement of Mecahnical Engineering, Polytechnic of South Aceh, Tapaktuan, Indonesia \\ ${ }^{b}$ Departement of Mecahnical Engineering, Abulyatama University, Lampoh Keudee, Indonesia \\ ${ }^{c}$ Departement of Civil Engineering, AlMuslim University,Peusangan, Indonesia \\ ${ }^{1}$ lindawati203@gmail.com*
}

ARTICLE INFO

Article history:

Accepted

Keywords:

Marble

South Aceh

Physical

Chemical

\begin{abstract}
Marble is a metamorphic rock that is widely distributed in the Earth's continental layer. Regarding its antiquity and aesthetic appeal, it has been widely used as a construction material such as flooring tiles in buildings and monument. Physical and chemical properties of natural stones play an important role on deciding their application area as a building stone. This study reports the physicochemical analysis of marble stones from the Gunung Kerambil (GK), Alur Kering (AK) and Meukek (M) area in South Aceh District. Density, water absorption and chemical analyses of the marble samples were determined. Physical properties of samples were determined through laboratory measurements. Chemical characterizations were made using X-ray Fluorescence (XRF) method. Based on,water absorption test results, the marbles from South Aceh are applicable for tile application.
\end{abstract}

Copyright $(C 2020$ Politeknik Aceh Selatan. All rights reserved.

\section{Introduction}

The utilization of natural resources has been increased due to the increasing demand for their uses in contemporary building decoration. The natural stone resources present the distinguished characteristics compare to other mineral resources regarding the availability of different types and colors that can be present in the same area [1]. Among natural stones, marble offers attractive and sophisticated appearance. Marble is a metamorphic rock that is widely distributed in the Earth's continental layer. It consists of a number of minerals, especially calcium carbonate. Seeing as antiquity and aesthetic appeal, it has been used as a construction material such as flooring tiles in buildings and monuments [2-5].

South Aceh, is a district with abundant marble resources. To date, the South Aceh marble is generally found in various colors in including white, grey, and dark, often occurring in combination. Despite its high quantity, marbles from South Aceh has been not properly utilized. This is primarily because the potentialities of these marbles are not evaluated, which are very important to the choice of any deposit for a particular purpose. In the past some work has been carried out on the evaluation of appearance and mineralogical properties of these marbles [6-7]. In order to enhance their use for building material and other potential industrial applications, the physical and chemical properties of the marbles need to be analyzed. Knowing the physical properties of rocks can determine the quality of the marble. Thus, this paper aims to contribute to the study of physicochemical properties of marble samples from Gunung Kerambil, Alur Kering and Meukek area in South Aceh District, to evaluate their potential as raw materials and to discover its suitability for industrial purposes. 


\section{Method}

\section{A. Samples}

The marble samples from South Aceh shown in Table 1. The samples were collected and prepared for physical and chemical properties test, including density, water absorption and chemical composition. The physically and chemically assessment testing was conducted through Laboratory Measurement.

\section{B. Characterization}

Among of the important physical properties of natural stone used for tile application are the density and water absorption. The procedures for the determination of these parameters are discussed below:

Density $(\rho)$

Density was measured volume and mass of dry sample (W) that is expressed in units of mass (kg or $\mathrm{g})$ per unit of volume $\left(\mathrm{m}^{3}\right.$ or $\mathrm{cm}^{3}$ or $\left.\mathrm{mm}^{3}\right)$ as follow formula:

$$
\rho=\frac{m}{v}
$$

\section{Water Absorption}

Water absorption was determined by weighing samples and drying in an oven at $100^{\circ} \mathrm{C}$ for $30 \mathrm{mins}$ to eliminate moisture. The oven dried rock samples were then weighed and soaked in water for 24 hours, 48 hours and 72 hours, wiped dry, and weighed again. The capacity of water absorbed was calculated based on the difference in soaked weights divided by the dry weight and multiplied by 100 to give the percentage of water absorption [8]. This is expressed mathematically as:

$$
\text { Water Absorption }=\frac{M s a t-M d}{M d} \times 100 \%
$$

\section{Chemical Analysis}

Chemical analyses of the marble samples were carried out using the X-ray fluorescence (XRF) method. The principle of samples characterization using XRF is done by utilizing X-rays emitted by the sample. The beam is then captured by the detector to be analyzed for the percentage of elements contained in the material.

\section{Results and Discussion}

\section{A. Physical Characterization}

\section{Colour}

Table 1 shows colour and basic specification of sample from Gunung Kerambil, Alur Kering and Meukek.

Table 1 Colour of investigated sample

\begin{tabular}{ccc}
\hline Samples & Colour & Specification \\
\hline GK & White & White with black veins \\
\hline AK & Black & Black with white veins \\
\hline M & Grey & Grey with white and red veins \\
\hline
\end{tabular}


Density

The results to the density measured for marbles from South Aceh is tabulated in Table 2. It was found that density from marble samples are around 2,64 and $2,71 \mathrm{~g} / \mathrm{cm} 3$. The highest density was showed by sample from Meukek, while the lowest density was showed by sample from Gunung Kerambil. In References, the density of marble is stated ranging from 2,56 to $2,75 \mathrm{~g} / \mathrm{cm}^{3}[9]$. As a result, the marble samples from South Aceh have measured density within values as it should be for common marbles. Density is a physical property that changes significantly due to mineralogy and porosity.

Table 2. Density of Marble Samples

\begin{tabular}{cc}
\hline Samples & Density $\left(\mathbf{g} / \mathbf{c m}^{\mathbf{3}}\right)$ \\
\hline GK & 2,64 \\
\hline AK & 2,69 \\
\hline M & 2,71
\end{tabular}

\section{Water Absorption}

Water absorption (WA) value is one of the most important issues for marble which have an effect on their physical and mechanical properties when considering for building stones [10]. Figure 1 presents that the amount of water absorbed by the samples after immersed in water for 24 hours, 48 hours, and 72 hours is below $1 \%$. The highest water absorption, $0,07 \%$, was performed by sample from Meukek after 48 hours immersion. The lowest water absorption, $0,002 \%$, was performed by sample from Gunung Kerambil after 72 hours of immersion. In accordance with SII. 0378-80 about physical condition of marble, based on the Decree of the Minister of Industry of the Republic of Indonesia (1981), water absorption of marble used for tile application is must less than $0,75 \%$ [1112]. Based on the water absorption finding, marbles from South Aceh are applicable for tile application. In addition, the low water absorption of the material is proved for its application in humid environments [13].

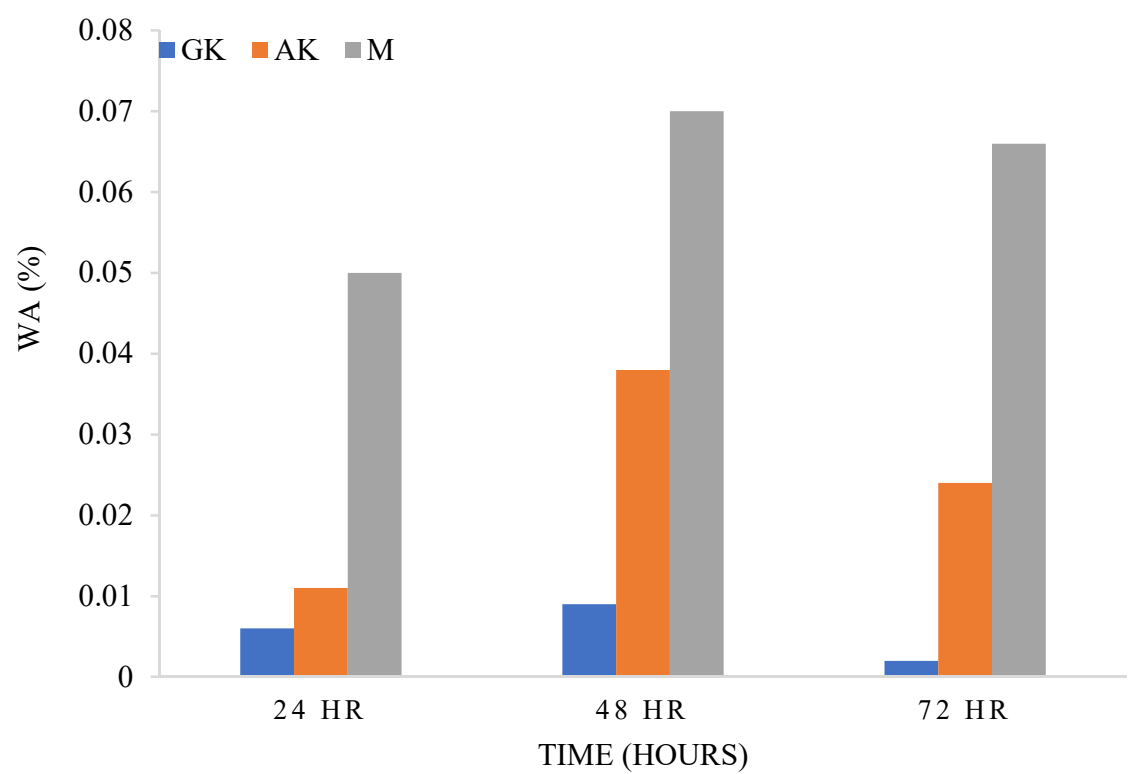

Fig. 1. Water Absorption of Marble Samples

\section{Chemical Analysis}

Table 3 shows the results of the chemical analysis. As seen in Table, the highest number of elements contained in the sample from Gunung Kerambil are $\mathrm{Sb}, \mathrm{Ag}, \mathrm{Fe}, \mathrm{Al}, \mathrm{S}$, and $\mathrm{Si}$ with the content 
percentage of $88,518 \%, 3,590 \%, 2,423 \%, 1,996 \%, 1,521 \%$ and $1,178 \%$. The highest number of elemental consisted in marble from Meukek area are $\mathrm{Sb}, \mathrm{Fe}, \mathrm{Al}, \mathrm{Ag}, \mathrm{S}$ and $\mathrm{Si}$ with content percentage of $82,999 \%, 5,853 \%, 5,095 \%, 3,423 \%, 1,214 \%$ and $0.937 \%$, respectively. On the other hand, the highest number of elements in Alur Kering Marble are $\mathrm{Sb}, \mathrm{Al}, \mathrm{Fb}, \mathrm{Ag}$, and $\mathrm{P}$ with percentage of content of $81,093 \%, 6,179 \%, 4,908 \%, 3,265 \%$ and 1,804\%, respectively. As a result, South Aceh marble is highly consisted of $\mathrm{Sb}$ with a percentage above $80 \%$.

Chemical analysis (wt\%) of the investigated samples

\begin{tabular}{cccc}
\hline \multirow{2}{*}{ Element } & \multicolumn{3}{c}{ Samples } \\
\cline { 2 - 4 } & GK & AK & M \\
\hline $\mathrm{Mg}$ & 0.169 & 0.068 & 0.320 \\
\hline $\mathrm{Al}$ & 1.996 & 5.095 & 6.179 \\
\hline $\mathrm{Si}$ & 1.178 & 0.937 & 0.085 \\
\hline $\mathrm{P}$ & 0.082 & 0.082 & 1.804 \\
\hline $\mathrm{S}$ & 1.521 & 1.214 & 0 \\
\hline $\mathrm{Cr}$ & 0 & 0.090 & 0 \\
\hline $\mathrm{Mn}$ & 0.289 & 0.115 & 0.204 \\
\hline $\mathrm{Fe}$ & 2.423 & 5.853 & 4.908 \\
\hline $\mathrm{Zn}$ & 0 & 0.063 & 0.101 \\
\hline $\mathrm{Zr}$ & 0.233 & 0.053 & 0.067 \\
\hline $\mathrm{Ag}$ & 3.590 & 3.423 & 3.265 \\
\hline $\mathrm{Sb}$ & 88.518 & 82.999 & 81.093 \\
\hline
\end{tabular}

The content of elements tested in Table 3 are different with the elements resulted in XRD analysis in previous study [7]. The greatest differences are related to the contents of Sb. Based on XRD analysis, South Aceh marbles are highly composed of Calcium Carbonate ( $\mathrm{Ca}$ and $\mathrm{O}$ ). This compositional difference can be caused by inaccurate step taken in sample preparation for chemical analysis. In consequent, it is necessary to retest the chemical composition of investigated samples.

\section{Conclusion}

This study has been carried out to evaluate the physical and chemical properties of marble samples from three areas in South Aceh District. The results show that sample from Gunung Kerambil region has lower density than those two samples. Sample from Meukek region has higher density than those two samples. Water absorption values of marble samples after immersed in water for 24 hours, 48 hours, and 72 hours are below 1\%. Those samples are appropriate to be used for tile application. Based on chemical analysis, the marble sample from South Aceh contained above $80 \%$ of Sb element. In general, density, water absorption and chemical composition played a major role determining marble quality.

\section{Acknowledgment}

Authors thank Indonesian Minister of Education and Culture for the research funding through Beginner Lecturer-Research Program year 2019.

\section{References}

[1] G. M. A. Wahab, M. Gouda, and G. Ibrahim, "Study of Physical and Mechanical Properties 
for Some of Eastern Desert Dimension Marble and Granite Utilized in Building Decoration," Ain Shams Eng. J., Vol. 10, No. 4, pp. 907-915, 2019.

[2] B. Tufan and M. Kun, "Thermal Insulation Performance and Thermal Conductivity Evaluation of Natural Stones by Infrared Thermography," Proc. Int. Conf. Mining, Mater. Metall. Eng. Prague, Czech Repub., August 11-12, pp. 1-9, 2014.

[3] M. B. Baker, "The Application of Marble and Granite as Building Materials in Jordan," Jordan J. Civ. Eng., Vol. 11, No. 2, pp. 234-238, 2017.

[4] O. A. Daku, S.S., Wazoh, H.N and Ojo, "Engineering Properties of Jakura Marble and Its Suitability for Tiles Production," IOSR J. Appl. Geol. Geophys., vol. 05, no. 01, pp. 57-66, 2017.

[5] F. Asdrubali, G. Baldinelli, F. Bianchi, A. Presciutti, F. Rossi, and S. Schiavoni, "Thermal and Optical Characterization ff Natural and Artificial Marble for Roof and External Floor Installations," J. Phys. Conf. Ser., Vol. 655, No. 1, 2015.

[6] A. Lindawati Lindawati, Nuzuli Fitriadi, "Analysis of Noise Level Generated by Stone Cutter Machine A Case Study in Marble Production Unit, South Aceh," J. Inov. Teknol. dan Rekayasa, vol. 3, no. 1, pp. 53-58, 2018.

[7] L. Lindawati, M. Mursal, I. Irwansyah, N. Fitriadi, and E. Saputra, "Mineral Identification of South Aceh Marble by Using X-Ray Diffraction Method," IOP Conf. Ser. Mater. Sci. Eng., vol. 536, no. 1, 2019.

[8] A. I. Saliu, M. A. and Lawal, "Investigations of Weathering Effects on Engineering Properties of Supare," J. Min. World Express, vol. 3, no. 0, pp. 53-62, 2014.

[9] https://chem.libretexts.org/Bookshelves/Ancillary_Materials/Exemplars_and_Case_Studies/ Exemplars/Geology/Density_of_Rocks_and_Soils

[10] Y. Ozcelik and A. Ozguven, "Water absorption and drying features of different natural building stones," Constr. Build. Mater., vol. 63, no. July 2014, pp. 257-270, 2014.

[11] Intan Paramita Haty, "Pemanfaatan Batu Marmer Berdasarkan Analisa Kuat Tekan Dan Serapan Air Daerah Teras Kecamatan Campurdarat Kabupaten Tulungagung Propinsi Jawa Timur," J. Ilm. MTG, vol. 4, no. 2, 2011.

[12] S. Kurniawati and D. Titisari, "Rekomendasi Pemanfaatan Marmer Berdasarkan Karakteristiknya terjadi dan dapat memberikan ciri khusus pada hasil batuannya baik dari sifat fisik Kecamatan Besuki, Kabupaten Tulungagung, Provinsi Jawa Timur memiliki jumlah," J. Pengabdi. Kpd. Masy., vol. 5 (2), no. Agustus, pp. 251-266, 2019.

[13] F. S. S. Tcharllis João da Cunha Demartini, Rubén Jesus Sánchez Rodríguez, "Physical and mechanical evaluation of artificial marble produced with dolomitic marble residue processed by diamond-plated bladed gang-saws," J. Mater. Res. Technol., vol. 7, no. 3, pp. 308-313, 2018. 